\title{
Glossary of abbreviations and definitions
}

ACCA

ACDOI

ACIL Tasman

Exploration Review

ACIL 2000 Review

AMPLA

AOPGGSA

AOPRMR Review

APA

APPEA

APRRT

APSLA

ARER

ARMAR

ARSR

$\mathrm{BCM}$ of gas

BOE
Competition and Consumer Act 2010 (Cth)

Commonwealth Department of Industry,

Science and Tourism

ACIL Tasman, Review of Australia's Offshore

Petroleum Exploration Policy (3 January 2012)

ACIL Consulting, National Competition

Policy Review of the Petroleum (Submerged

Lands) Legislation (Report to the Petroleum

(Submerged Lands) Review Committee, 2000)

Australian Resources and Energy Law

Association

Offshore Petroleum and Greenhouse Gas

Storage Act 2006 (Cth)

Department of Industry, Innovation and

Science, Offshore Petroleum Resource

Management Review (Interim Report,

Australian Government November 2015)

Awards in Predefined Areas (Norway)

Australian Petroleum Production and

Exploration Association

Petroleum Resource Rent Tax Australia

Petroleum (Submerged Lands) Act 1967 (Cth)

Offshore Petroleum and Greenhouse Gas

Storage (Environment) Regulations 2009 (Cth)

Offshore Petroleum Greenhouse Gas

and Storage (Resource Management and

Administration) Regulations 2012 (Cth)

Offshore Petroleum Greenhouse Gas and

Storage (Safety) Regulations 2009 (Cth)

Billion cubic metres of gas

Barrels of Oil Equivalent 
Brownfields

MER Report

Bunter

CSA

CSG

Daintith and Chandler

Daintith Discretion

Daintith, Willoughby and Hill

DCF

DECC

DEFRA

EIA

E\&P

EPBC

ESG

FDP

Former

UKFDP Guidance

GDP

GRI

GSE

GST

GTL

Henry Tax Review

IEA

IMF
PILOT, Maximising Economic Recovery of the UK's Oil and Gas Reserves - Context for the Brownfields Challenge (Brownfields Studies, March 2005) Michael Bunter, The Promotion and Licensing of Petroleum Prospective Acreage (Kluwer Law International 2002)

Continental Shelf Act 1964 (UK)

Coal Seam Gas

Terence Daintith and John Chandler, 'Offshore petroleum regulation: theory and disaster as drivers for institutional change' (2017) 39 Houston Journal of International Law 333

Terence Daintith, Discretion in the Administration of Offshore Oil and Gas A Comparative Study (AMPLA 2005)

TC Daintith, GDM Willoughby and ADG Hill (eds), United Kingdom Oil and Gas Law (3rd edn, loose leaf, Sweet \& Maxwell 2000) discounted cash flow

Department of Energy and Climate Change (UK)

Department for Environment, Food and Rural Affairs (UK)

Environmental Impact Assessment

Exploration and Production

Environmental Protection and Biodiversity

Conservation Act 1999 (Cth)

Environmental, Social and Governance

Field Development Plan

Oil and Gas Authority, Oil and gas: fields and

field development (January 2013)

Gross Domestic Product

Global Reporting Initiative

Government Sponsored Enterprises

Goods and Services Tax

Gas-to-liquids

Commonwealth of Australia, Australia's

future tax system - Report to the Treasurer

(December 2009)

International Energy Agency

International Monetary Fund 
Infrastructure

IOC

JOA

JV

KPI

LNG

LPG

MBEIS

MC

McDonald

MERUKS

MMbbl

Montara

Inquiry Report

NCSA

NCS

NES

NGL

NMPE

NMPE 2011

Industry Review

NOC

NOK

NOPSEMA

NOPTA

NPA
Generally used to mean the wells, subsea pipelines, platforms, treatment and storage facilities, worker accommodation and other infrastructure and facilities required for production and storage of hydrocarbons in an offshore project; excluding ships and similar facilities

International Oil Company

Joint Operating Agreement

Joint Venture

Key Performance Indicator

Liquefied Natural Gas

Liquefied Petroleum Gas

Ministry for Business, Energy and Industrial Strategy (UK)

Model Clauses (UK)

Stephen L McDonald, Petroleum Conservation in the United States: An Economic Analysis

(The Johns Hopkins Press 1971)

Oil and Gas Authority, The Maximising Economic Recovery Strategy for the UK

(Department for Business, Energy \&

Industrial Strategy March 2016)

One million barrels

David Borthwick AO PSM, Report of

Montara Commission of Inquiry (June 2010)

Continental Shelf Act 1963 (Norway)

Norwegian Continental Shelf

New Energy Solutions

Natural Gas Liquids

Norwegian Ministry of Petroleum and Energy

Norwegian Ministry of Petroleum and

Energy, An industry for the future - Norway's

Petroleum activities (Meld. St. 28 (2010-2011)

Report to the Storting (white paper))

National Oil Company

Norwegian Krone

National Offshore Petroleum Safety and

Environmental Management Authority (Cth)

National Offshore Petroleum Titles

Administrator (Cth)

Petroleum Act 1996 (Norway) 
NPD

NPDO

NPDO Guideline

NPR

OCS

OECD

OECD Regulation

Governance

OECD Risk

Governance

OGA

OGA Asset

Stewardship

Expectations

OGA Asset Stewardship

Strategy

OGP

OPEC

PGERA

PIO

PPA

PRT

PSC

Regulatory

Burden Review

RFCT

Roggenkamp
Norwegian Petroleum Directorate

Plan for Development and Operation (Norway)

The Ministry of Petroleum and Energy and the Ministry of Labour and Social Affairs, Guidelines for plan for development and operation of a petroleum deposit (PDO) and plan for installation and operation of facilities for transport and utilisation of petroleum (PIO) (June 2017)

Petroleum Regulations (Norway)

Offshore Constitutional Settlement

Organisation for Economic Co-Operation and Development

OECD, The Governance of Regulators (Best

Practice Principles for Regulatory Policy,

OECD Publishing 2014)

OECD, Risk and Regulatory Policy

Improving the Governance of Risk (OECD

Reviews of Regulatory Reform, OECD

Publishing, 2010)

Oil and Gas Authority (UK)

Oil and Gas Authority, Asset

Stewardship Expectations (October 2016)

Oil and Gas Authority, Asset Stewardship

Strategy October 2016)

International Association of Oil and Gas

Producers

Organization of Petroleum Exporting

Countries

Petroleum and Geothermal Energy Resources Act 1967 (WA)

Plan for installation and operation of facilities for transport and utilisation of petroleum Petroleum (Production) Act 1998 (UK)

petroleum revenue tax

Production Sharing Contract

Australian Productivity Commission, Review

of Regulatory Burden on the Upstream (Oil

and Gas) Sector (2009)

Ring Fence Corporation Tax

Martha Roggenkamp, Catherine Redgewell, 
Ryggvik

SECR

SECR Consultation

Smith

Taverne

UKCA

UKCS

UKEA

UKEA 2011

UKFDP

UKFDP Guidance

UKIA

UKPA

UKPLPSR

UKPRT

UKSR Guidance

UNCLOS

Wood Review

World Bank Paper 179
Inigo del Guayo and Anita Ronne (eds), Energy Law in Europe (3rd edn, Oxford University Press 2016)

Helge Ryggvik, 'The Norwegian Oil

Experience: a toolbox for managing resources'. http://www.sv.uio.no/tik/forskning/ publikasjoner/tik-rapportserie/Ryggvik.pdf Satisfactory expected commercial return Oil and Gas Authority, Consultation on the approach to "satisfactory expected commercial return" in the MER UK Strategy (13

December 2017)

E Smith, J Dzienkowski, O Anderson,

L Lowe, B Kramer and J Weaver, International

Petroleum Transactions (3rd edn, Rocky

Mountain Mineral Law Foundation 2013)

Bernard Taverne, Petroleum, Industry and

Governments (3rd edn, Wolters Kluwer 2013)

Competition Act 1998 (UK)

United Kingdom Continental Shelf

Energy Act 2016 (UK)

Energy Act 2011 (UK)

Field Development Plan (UK)

Oil and Gas Authority, Guidance on the preparation and content of offshore oil and gas field development plans (June 2017)

Infrastructure Act 2015 (UK)

Petroleum Act 1998 (UK)

Petroleum Licensing (Production) (Seaward

Areas) Regulations 2008 (UK)

Petroleum Revenue Tax (UK)

Oil and Gas Authority, Stewardship Review

Guidance (March 2017)

United Nations Convention on the Law of the

Sea 1982

Sir Ian Wood, UKCS Maximising Recovery

Review: Final Report (24 February 2014)

Silvano Tordo, David Johnston and Daniel

Johnston, Petroleum Exploration and

Production Rights Allocation Strategies and

Design Issues (World Bank Working Paper No.

179, 2010) 